\title{
DESAIN ANTENA MIKROSTRIP DOUBLE TRIANGULAR PATCH DENGAN SLOT Y UNTUK APLIKASI PENGUAT SINYAL 4G PADA FREKUENSI $1800 \mathrm{MHz}$
}

\author{
Yenniwarti Rafsyam ${ }^{1}$, Alica Dewanti ${ }^{2}$, Shita Fitria Nurjihan ${ }^{3}$ \\ ${ }^{1,2,3}$ Program Studi Telekomunikasi, Jurusan Teknik Elektro, Politeknik Negeri Jakarta \\ Jl. Prof. Dr. G.A. Siwabessy, Kampus UI, Depok, 16425, Indonesia \\ E-mail: yennirafsyam@gmail.com
}

\begin{abstract}
Abstrak
Long Term Evolution (LTE) merupakan teknologi 4th generation (4G) yang digunakan sebagai teknologi seluler. LTE bekerja di berbagai band frekuensi, salah satunya pada band $1800 \mathrm{MHz}$. Pada tiap lokasi, level sinyal yang akan diterima oleh pengguna berbeda-beda tergantung dari lokasi pemakaian. Pada lokasi di dalam ruangan, level sinyal akan melemah dikarenakan melewati penghalang seperti pepohonan atau tembok, sehingga level sinyal yang diterima pengguna kurang maksimal. Untuk memperbaiki kondisi tersebut, diperlukan sebuah penguat. Penguat tersebut memerlukan antena sebagai penerima sinyal yang dipancarkan dari eNodeB dan antena untuk memancarkan sinyal yang telah dikuatkan. Pada tulisan ini di bahas tentang perancangan antena mikrostrip double triangular patch dengan slot Y sebagai antena indoor yang digunakan untuk memancarkan sinyal yang bekerja pada frekuensi $1800 \mathrm{MHz}$. Hasil rancangan menunjukkan bahwa antena mikrostrip yang telah difabrikasi dan diuji memiliki nilai spesifikasi sesuai dengan yang diinginkan yaitu return loss $=-20,702 \mathrm{~dB}, \mathrm{VSWR}=1,1566$, gain $=6,9 \mathrm{~dB}$, dan pola radiasi unidirectional Sedangkan hasil pengujian level sinyal antena yang dilakukan pada tiga lokasi menggunakan empat provider menunjukkan bahwa nilai level sinyal tertinggi diperoleh oleh provider Telkomsel yaitu $-77 \mathrm{dBm}$ dan yang terendah adalah provider XL yaitu $-110,6 \mathrm{dBm}$.
\end{abstract}

Kata Kunci : 4G, antena, frekuensi $1800 \mathrm{MHz}$, level sinyal, mikrostrip, patch double triangular

\begin{abstract}
Long Term Evolution (LTE) is 4th generation (4G) technology that used as cellular technology. LTE works in various bands, one of band is $1800 \mathrm{MHz}$. At each location, the signal level that will received by the user varies depending on the usage location. At indoor location, signal level will weaken due to passing the obstacle like trees or walls, so the signal level that the user receivers is less than the maximum. To improve this condition, a repeater is needed. a repeater need an antenna as a signal receiver that transmitted from eNodeB and an antenna for transmitting a signal that has been amplified. In this paper will be explained about design an antenna microstrip double triangular patch with slot $Y$ as an indoor antenna that used for transmitting a signal that works at frequency $1800 \mathrm{MHz}$. Micostrip antenna that was fabricated and tested has specification value is obtained which are return loss $=-20,702 \mathrm{~dB}$, VSWR $=1,1566$, gain $=$ $6,9 \mathrm{~dB}$, and the radiation pattern is unidirectional. Signal level antenna testing is performed on three location by using four provider. The highest signal level gained by Telkomsel provider that is $-77 \mathrm{dBm}$ and the lowest is XL provider that is $-100,6 \mathrm{dBm}$.
\end{abstract}

Keywords : 4G, antenna, frequency $1800 \mathrm{MHz}$, microstrip, patch double triangular, signal level

\section{Pendahuluan}

Long Term Evolution (LTE) merupakan teknologi radio 4G yang mengacu pada standar third generation partnership project (3GPP) Release 8 yang secara teoritis mendukung kecepatan pengiriman data mencapai $100 \mathrm{Mbps}$ untuk downlink dan $50 \mathrm{Mbps}$ untuk uplink. Kecepatan ini dapat dicapai dengan menggunakan orthogonal frequency division 
multiplexing (OFDM) pada uplink dan single carrier frequency division multiplex (SC-FDMA) pada uplink yang digabungkan dengan penggunaan multiple input multiple output (MIMO). LTE mampu menyediakan efisiensi spektrum yang baik, peningkatan kapasitas radio, biaya operasional yang lebih rendah bagi operator serta kualitas layanan mobile broadband tinggi. Selain itu, LTE juga menawarkan fleksibilitas dalam hal spectrum. LTE dapat beroperasi pada standar IMT-2000 maupun pada pita spektrum baru seperti $700 \mathrm{MHz}$ dan $2.5 \mathrm{GHz}$. Alokasi pita lebar yang sangat fleksibel, mulai dari $1.5 \mathrm{MHz}$ sampai dengan $20 \mathrm{MHz}$.

Pada masa kini, seringkali ditemukan adanya masalah saat menggunakan teknologi LTE yaitu hilangnya sinyal pada layanan LTE di suatu tempat tertentu. Salah satu penyebabnya ialah tebalnya konstruksi bangunan sehingga sinyal $4 \mathrm{G}$ yang dipancarkan oleh eNodeB ke daerah tersebut tidak dapat ter-cover dan mengakibatkan kegiatan yang membutuhkan layanan $4 \mathrm{G}$ tidak dapat dilakukan. Kondisi ini mengarah kepada kebutuhan sebuah sistem yang terdiri dari antena penerima untuk menangkap sinyal $4 \mathrm{G}$ dari eNodeB. Kemudian sinyal yang diterima akan dikuatkan menggunakan perangkat repeater dan diteruskan ke antena pemancar untuk daerah yang belum atau sulit mendapatkan sinyal 4G, sehingga kegiatan yang membutuhkan sinyal $4 \mathrm{G}$ dapat dilakukan. Saat ini telah dikembangkan berbagai macam bentuk patch dari antena mikrostrip, seperti segi empat (rectangular), segitiga, lingkaran, cincin (ring), elips, dan lain-lain [2].

Tulisan ini membahas tentang perancangan antena mikrostrip double triangular patch dengan slot $Y$ untuk aplikasi penguat sinyal 4G pada frekuensi $1800 \mathrm{MHz}$.

\section{Metode Penelitian}

Dalam metode ini terdapat beberapa tahapan untuk menguji fungsi antena mikrostrip double triangular patch dengan slot $\mathrm{Y}$ sebagai antena transmitter untuk aplikasi repeater sebagai penguat sinyal 4G. Tahap pertama adalah pembuatan antenna yang akan dipakai pada tahap pengujian yaitu antena mikrostrip double triangular patch dengan slot Y. Setelah membuat antena, selanjutnya dilakukan pengujian pada tiga lokasi yakni: (i) Jl. Swadaya 1, Beji, (ii) Laboratorium Telekomunikasi PNJ dan (iii) Pancoran Mas, Depok.

Untuk membuat antena terlebih dahulu dilakukan perancangan dengan menentukan ukuran patch dari segitiga sama sisi. Bentuk segitiga memiliki keunggulan dibandingkan dengan bentuk segiempat, yaitu untuk menghasilkan karakteristik radiasi yang sama, luas yang dibutuhkan oleh bentuk segitiga lebih kecil dibandingkan dengan luas yang dibutuhkan oleh segi empat. Hal ini sangat menguntungkan dalam fabrikasi antena [3]. Perhitungan pertama dilakukan menggunakan Pers. (1) untuk menngetahui ukuran sisi segitiga.

$a=\frac{2 c}{3 \times f \times \sqrt{4,3}}$

$a=\frac{2 c}{3 \times 1,8 \times 10^{9} \times \sqrt{4,3}}=5,35 \mathrm{~mm}$

dengan $a$ adalah panjang sisi segitiga, $f$ adalah frekuensi dan $c$ adalah kecepatan cahaya.

Setelah panjang sisi segitiga diperoleh, maka perhitungan jari-jari (r) segitiga dilakukan dengan menggunakan Pers. (2).

$\mathrm{r}=\frac{\mathrm{a}}{\sqrt{3}}$

$r=\frac{5.35}{\sqrt{3}}=30,88 \mathrm{~mm}$

Setelah mendapatkan tinggi segitiga, selanjutnya menghitung jarak antar patch (d) menggunakan Pers. (3).

$\mathrm{d}=\frac{\lambda}{2}=\frac{\mathrm{c}}{2 \mathrm{f}}$

$\mathrm{d}=\frac{3 \times 10^{8}}{2 \times 1.8 \times 10^{9}}=83,3 \mathrm{~mm}$

Setelah melakukan perancangan patch antena, dilakukan perancangan saluran transmisi. Pada perancangan ini, digunakan tiga jenis saluran transmisi, yaitu Wzo dengan impedansi saluran sebesar $50 \Omega$, Wzt dengan impedansi saluran sebesar $75 \Omega$ dan Wzl dengan impedansi saluran sebesar $100 \Omega$.

Perhitungan saluran transmisi dilakukan dengan Pers. (4-6).

$\mathrm{Wzo}=\frac{377}{\sqrt{4.3}}\left(\frac{2.5}{50}\right)$

$\mathrm{Wzo}=9,09 \mathrm{~mm}$

$\mathrm{Wzt}=\frac{377}{\sqrt{4.3}}\left(\frac{2.5}{75}\right)$

$\mathrm{Wzt}=6,06 \mathrm{~mm}$

$\mathrm{Wzl}=\frac{377}{\sqrt{4.3}}\left(\frac{2.5}{100}\right)$

$\mathrm{Wzl}=4,54 \mathrm{~mm}$

Setelah didapat perhitungan, diperoleh dimensi antena seperti Gambar 1 . 


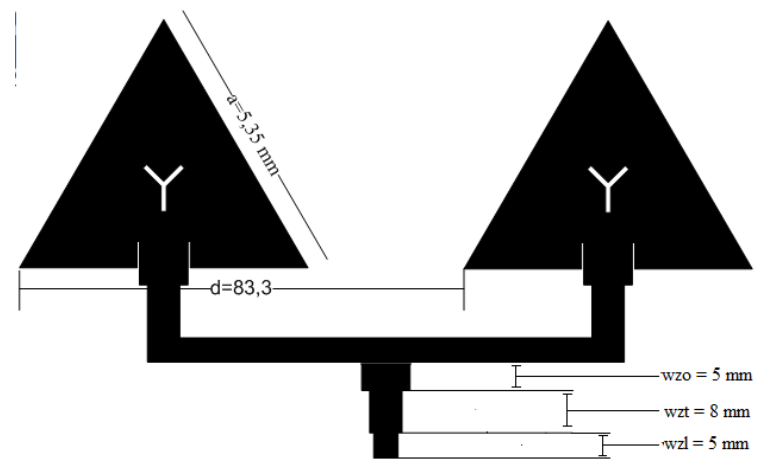

Gambar 1. Desain antena mikrostrip double triangular patch dengan slot $\mathrm{Y}$ berdasarkan hasil perhitungan

Setelah mendapat ukuran dari hasil perhitungan, maka selanjutnya disimulasikan pada software CST untuk mendapatkan hasil parameter yang diinginkan. Setelah parameter yang diinginkan didapat, maka dilakukan fabrikasi. Setelah antena sudah difabrikasi selanjutnya melakukan pengujian.

\section{Hasil dan Pembahasan}

Antena yang telah difabrikasi dilakukan pengujian untuk mengetahui penguatan level daya sinyal di Laboratorium Telekomunikasi Politeknik Negeri Jakarta. Pengujian dilakukan dengan menggunakan empat provider yaitu Telkomsel, Indosat Ooreedo, XL, dan Three (3). Antena double triangular patch dengan slot $Y$ (MDTY) digunakan sebagai antena indoor (transmitter) dan antena default digunakan sebagai antena outdoor (receiver). Pengujian dilakukan di 3 lokasi yaitu Jalan Swadaya Beji, Laboratorium Telekomunikasi, dan pancoran mas Depok. Set up rangkaian untuk pengujian ditunjukkan pada Gambar 2.

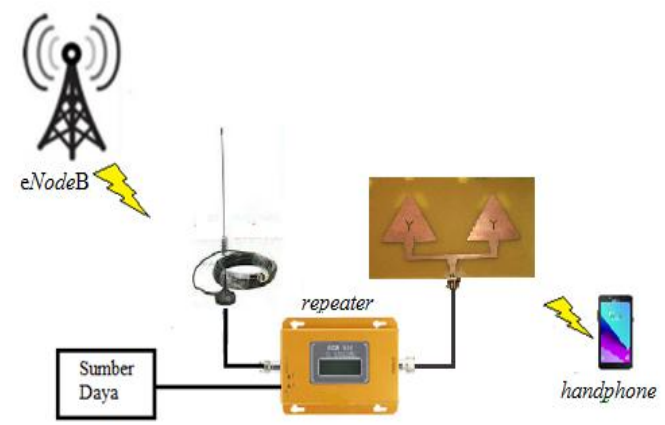

Gambar 2. Set up Rangkaian Menggunakan Antena MDTY dan Antena Default

Setelah merangkai antena sesuai set up rangkaian yang dimaksud, maka dilakukan pengujian. Pengujian dilakukan untuk mendapatkan level sinyal yang berbeda-beda yang nantinya akan menjadi perbandingan.. Hasil pengujian yang dilakukan di Jl. Swadaya 1 Beji ditampilkan pada Tabel 1.

Tabel 1. Hasil Pengujian di Jl. Swadaya 1 Beji

\begin{tabular}{ccc}
\hline \multirow{2}{*}{ Provider } & \multicolumn{2}{c}{ Level Sinyal Rata-rata (dBm) } \\
\cline { 2 - 3 } & Antena MDTY & $\begin{array}{c}\text { Tanpa Antena } \\
\text { MDTY }\end{array}$ \\
\hline Telkomsel & -109 & $-107,6$ \\
Indosat Ooredoo & $-89,5$ & $-95,4$ \\
XL & $-110,6$ & $-117,8$ \\
Three (3) & -85 & $-104,4$ \\
\hline
\end{tabular}

Pada Tabel 1 dapat dilihat bahwa rata-rata kuat sinyal tertinggi pada provider Three yaitu $-85 \mathrm{dBm}$ saat kondisi menggunakan antena MDTY, sedangkan saat kondisi tanpa menggunakan antena MDTY rata-rata kuat sinyal tertinggi pada provider Indosat Ooredoo yaitu $-95,4 \mathrm{dBm}$.

Selanjutnya, pengujian dilakukan di Laboratorium Telekomunikasi PNJ yang hasilnya di tampilkan pada Tabel 2

Tabel 2. Hasil Pengujian di Laboratorium Telekomunikasi PNJ

\begin{tabular}{ccc}
\hline \multirow{2}{*}{ Provider } & \multicolumn{2}{c}{ Level Sinyal Rata-rata $(\mathrm{dBm})$} \\
\cline { 2 - 3 } & Antena MDTY & $\begin{array}{c}\text { Tanpa Antena } \\
\text { MDTY }\end{array}$ \\
\hline Telkomsel & $-80,6$ & $-99,6$ \\
Indosat Ooredoo & -83 & $-94,2$ \\
XL & -94 & $-98,6$ \\
Three (3) & $-83,8$ & $-96,4$ \\
\hline
\end{tabular}

Pada Tabel 2 dapat dilihat bahwa rata-rata kuat sinyal tertinggi pada provider Telkomsel yaitu -80,6 dBm saat kondisi menggunakan antena MDTY, sedangkan saat kondisi tanpa menggunakan antena MDTY rata-rata kuat sinyal tertinggi pada provider Indosat Ooredoo yaitu $94,2 \mathrm{dBm}$.

Selanjutnya, pengujian dilakukan di Pancoran Mas, Depok yang hasilnya di tampilkan pada Tabel 3. 
Tabel 3. Hasil Pengujian di Pancoran Mas, Depok

\begin{tabular}{ccc}
\hline \multirow{2}{*}{ Provider } & \multicolumn{2}{c}{ Level Sinyal Rata-rata $(\mathrm{dBm})$} \\
\cline { 2 - 3 } & Antena MDTY & $\begin{array}{c}\text { Tanpa Antena } \\
\text { MDTY }\end{array}$ \\
\hline Telkomsel & -77 & -100 \\
Indosat Ooredoo & $-90,6$ & $-104,6$ \\
XL & $-85,8$ & -96 \\
Three (3) & $-86,4$ & $-97,8$ \\
\hline
\end{tabular}

Pada Tabel 3 dapat dilihat bahwa rata-rata kuat sinyal tertinggi pada provider Telkomsel yaitu $-77 \mathrm{dBm}$ saat kondisi menggunakan antena MDTY, sedangkan saat kondisi tanpa menggunakan antena MDTY rata-rata kuat sinyal tertinggi pada provider XL yaitu $-96 \mathrm{dBm}$.

\section{Kesimpulan}

Dari hasil dan pembahasan pada bab sebelumnya, dapat diperoleh kesimpulan bahwa Dari hasil pengujian yang dilakukan, didapat level sinyal tertinggi saat kondisi menggunakan antena MDTY dimiliki oleh provider Telkomsel yaitu $-77 \mathrm{dBm}$ sedangkan saat kondisi tanpa menggunakan antena MDTY memiliki nilai rata-rata kuat sinyal sebesar $-100 \mathrm{dBm}$, dimana pengujian dilakukan di daerah Pancoran Mas, Depok. Dan level daya terendah saat kondisi menggunakan antena MDTY dimiliki oleh provider XL yaitu -110,6 dBm sedangkan saat kondisi tanpa menggunakan antena MDTY memiliki nilai rata-rata kuat sinyal sebesar $-117,8 \mathrm{dBm}$ dengan pengujian dilakukan di Jl. Swadaya 1, Beji.

\section{Daftar Acuan}

[1] Amirullah, Lestari, Rancang Bangun Antena Mikrostrip Dengan Menggunakan Teknik Defected Ground Structure (DGS) Bentuk Dumbbell SquareHead pada Patch Segitiga Array Linier, 2008.

[2] C.A. Balanis, Antenna Theory and Design 3rd Edition. New Jersey: John Wiley \& Sons, Inc, 2005.

[3] Zulkifli, F. Yuli, Pengembangan Antena Mikrostrip Susun Dua Elemen Dengan Penerapan Defected Ground Structure Berbentuk Trapesium, 2008.

[4] Sarfina, E. Aulia, Analisis Perancangan Antena Mikrostrip Patch Segitiga Array untuk Aplikasi WLAN 2,4 GHz, 2017.

[5] M. Ulfah, Analisa Coverage Area Jaringan 4G LTE, 2017.

[6] D. Kho. Pengertian Antena dan Parameter Karakteristiknya. 2015.

[7] Iksan, Fungsi Kabel Koaksial dan Kelebihannya, 2012. 